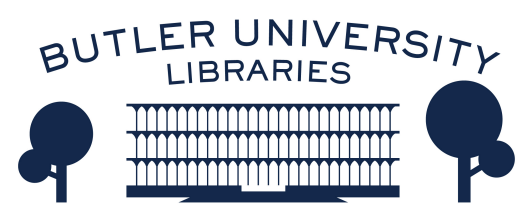

Journal of Hindu-Christian Studies

Volume 24

Article 13

November 2011

\title{
Book Review: "Being Different: An Indian Challenge to Western Universalism"
}

\author{
T. S. Rukmani
}

Follow this and additional works at: https://digitalcommons.butler.edu/jhcs

Part of the Religion Commons

\section{Recommended Citation}

Rukmani, T. S. (2011) "Book Review: "Being Different: An Indian Challenge to Western Universalism"," Journal of Hindu-Christian Studies: Vol. 24, Article 13.

Available at: https://doi.org/10.7825/2164-6279.1490

The Journal of Hindu-Christian Studies is a publication of the Society for Hindu-Christian Studies. The digital version is made available by Digital Commons @ Butler University. For questions about the Journal or the Society, please contact cbauman@butler.edu. For more information about Digital Commons @ Butler University, please contact digitalscholarship@butler.edu. 
immature, and that Ramakrishna was beyond that. This is indeed marginalizing Kali, and I think that Kripal's claim about this is correct; the authors of Interpreting Ramakrishna should not be "astounded" at his claim (p. 69).

It might also have been useful for Interpreting Ramakrishna to say something clearer about the role of the dissertation advisor in getting this thesis accepted and published. While Kripal had a limited amount of time in India and limited language skills, his advisor had more experience of India and should have been able to find errors of translation and cultural understanding. Instead, we have an advisor who did not check the sources, and supported giving the book an award, at least partly because it agreed with her own theories. It was this award that brought the book into its high-profile controversy. It is important for academia to have the equivalent of "due diligence" in law, in which the facts are checked before publication.

We might also rethink the claim in Interpreting Ramakrishna that such a negative view of Hindu saints and holy people is primarily due to Orientalism. Psychobiography often involves an equal-opportunity reductionism of spiritual experiences to material causes, and some of the most egregious attacks on saints may be found in the literature of female medieval Catholic saints, whose fasting becomes anorexia, whose visions are hallucinations, and whose love of God is due only to sexual frustration. There are psychobiographies portraying Muhammad as a psychopathic murderer, Gautama Buddha as a depersonalized depressive, Jesus as a victimized survivor, Saint Paul as an epileptic, the prophet Ezekiel as full of pathological dread and loathing, and Saint Teresa of Avila as a hysteric. One need not have a person from South Asia as the subject of such reductionist forms of psychoanalytic interpretation. Even the Judeo-
Christian God, Yahweh, has been interpreted in psychobiography as a jealous, narcissistic and genocidal tyrant. According to one recent book, Yahweh's behavior is irrational, vindictive, insecure, dangerous, malevolent, and abusive. ${ }^{2}$ This sort of exaggerated pathologizing has resulted in academic claims being discredited and devalued among many religious groups.

Attributions of sexual and violent impulses are ways to bring the transcendent back to earth, to place it in the sphere of human understanding and control. The psycho-analytic approach of "explaining the flower by the fertilizer" involves a universal claim, and imposes a model upon data where it does not always fit. Ramakrishna is a sort of Rorschach blot, "the embodiment of infinite bhavas," so he can be seen in many ways.

But if we hope to understand other cultures instead of getting into conflicts with them, greater empathy and clearer sight are needed. Perhaps it would be useful to have more academics who are also practitioners, like the authors of this book, who can walk the line between criticism and empathy. Interpreting Ramakrishna brings out some of the best of each side; it mixes the idealism and dedication of a meditative path with the critical scholarship and historical analysis of academia.

Notes

${ }^{1}$ Jeffrey Kripal, Kali's Child: The Mystical and the Erotic in the Life and Teachings of Ramakrishna. Chicago: University of Chicago Press, 1995.

${ }^{2}$ See David Penchansky, What Rough Beast: Images of God in the Hebrew Bible. Louisville: Westminster John Knox Press, 1999

June McDaniel

College of Charleston

\section{Being Different: An Indian Challenge to Western Universalism. Rajiv Malhotra. New Delhi: HarperCollins India, 2011. vii +471 pages}


RAJIV Malhotra has been in the forefront for the past 20 years and counting for clearing away some misconceptions regarding key concepts in Hinduism and other Indic traditions, which he has relentlessly pursued in spite of formidable opposition from academics and others alike. Any major book dealing with Hinduism these days generally acknowledges Rajiv in their works, whether to criticize or otherwise, as, for instance, Wendy Doniger's recent book on India's history (The Hindus: An Alternative History, 2009:652n). I am familiar with Rajiv's earlier books and find Being Different written in a much more balanced and reflective manner. This could be the result of his consultation with scholars from both the Dharma traditions (Satyanarayana Das, Sampadananda Mishra et al) and Judeo-Christian traditions (Gerry Larson, Francis Clooney et al) which he acknowledges in his book. While there is a slow recognition amongst scholars in the West of some of the issues that Rajiv raises, the opposition to his views in his own land of birth, India, is much more virulent and unrelenting, which may be attributed to the lack of an academic approach to the study of religion in India. Prejudices handed down in respective religious communities regarding other communities never gets a chance to be discussed in a classroom situation in India, because of its narrow, secularist educational policy, with the result that there is no chance of either appreciating the strengths or criticizing the weaknesses of these religious systems. India can and must wake up to this lacuna in its education policy before it is too late.

Coming back to the book, Being Different, it is primarily a detailed analysis of how the Indic dharmas' approach to religion differs from that of the Judeo-Christian traditions. Belonging to the genre of Orientalism or post-colonialism the book covers a vast territory, tackling topics as varied as "The Audacity of Difference," "Yoga: Freedom from History," "Integral Unity and Synthetic Unity," "Order and Chaos," "Nontranslatable Sanskrit versus Digestion" and "Contesting Western Universalism." While my first reaction was 'where is the need for a book of this kind when all this is already very well known?' I was rudely shaken out of my complacency by the recent statement of the senior pastor of the First Baptist Church, Dallas Rev. Jeffres regarding Mormonism as being a 'cult' and clubbing Hinduism, Buddhism and other faiths along with it. This reinforces what Rajiv states about the 'prejudices' and lack of respect that the Judeo-Christian mainstream in the West has for other faiths, including the Indic dharma traditions. This book of more than 470 pages with an exhaustive bibliography, copious notes and an index is a timely reminder of the challenges that religions other than the mainstream Judeo-Christian face to gain equal "respect" for their own religions. There is a lot of useful information on what distinguishes the Dharma traditions or Indic religions broadly from the Judeo-Christian, and the book addresses the misconceptions prevailing not only in the mainstream Western milieu but equally so amongst the Indian intellectuals of all shades and opinions.

Rajiv's main arguments spring from the thesis that the Judeo-Christian traditions are in general 'history centered' religions as opposed to Hinduism, which is 'rishi-centered' or which is "direct embodied knowing of the divine". All the chapters are very well researched, and the arguments are well developed. Chapter 3, titled "Integral Unity and Synthetic Unity," in particular has a number of concepts like 'Bandhu', 'Time', 'Flux', 'Non-linear Causation' and many more, explained with a richness of examples drawn from many disciplines such as religion, philosophy, art, architecture, dance, music etc (p. $116 \mathrm{ff}$ ). While in general the comparison between the 'dharma traditions' versus the 'history centered religions' rings true, Rajiv needs to curb the tendency to generalize while talking about paradigms like 'integral unity' versus 'synthetic unity' wherein the dharmic traditions' (according to him) "are steeped in the metaphysics of the non-separation of all reality, physical and non-physical" (p.102). This is repeated on page 116 and implied in other places as well. This is difficult to square with what one knows of the Dvaita Vedanta tradition. In Dvaita Vedanta there is an assertion of the five differences between jiva and God, between one jiva and another jiva, between jiva and matter, between God and matter and between matter and matter. So one will have to 
stretch one's imagination to fit Dvaita into the category of 'integral unity' in Rajiv's definition. Similarly while his attempt to pinpoint the differences can help not to collapse all 'religions' within one broad category of 'religion' and preserve their unique distinctions, one needs to be cautious as well when applying Sanskrit words to describe other traditions. Just as the Hindu resents his sacred writings being called the 'bible', to collapse Judeo-Christian religious texts into 'sruti' and 'smriti' may not square well with the theme of the book (pp.256-258 and elsewhere).

Chapters 1-4 have a tightness and focus relevant to the title of the book Being Different. However, the initial few pages of Chapter 5 (pp. 221-240) moves away from that focus and though a good introduction to the many-sided views concerning the philosophy of language (Sanskrit to be specific) it lacks a cohesion that the earlier chapters presented. These early pages dealing with the philosophy of language as represented in the different Sanskritic traditions with Aurobindo given a prominent place (maybe because of his having lived so close to our times) can easily belong to a separate paper and sits uncomfortably in this chapter. The spread of Sanskrit and its culture to many countries in Central Asia more by assimilation of its 'sanskriti' than by conquering its people (pp. 244-49), has some relevance to the main theme, as this is not very well known. It is a good summary of the way that 'sanskriti' got embedded in both the knowledge systems as well as the everyday lives of the people of these countries. Pages 249-306 of chapter 5 deal with the relevant question of translating words from one language to another, especially Sanskrit words that have multiple meanings. As is well known, once wrong translations get into the knowledge systems they can undermine a proper comprehension of the concept which the words convey, as has happened with words such as 'atman', 'deva', 'dharma', 'jivanmukti', 'moksha', 'samsara', and many more. It points to the truism that Sanskrit words, like other philosophically and spiritually loaded words in any language, cannot be translated into other languages and convey their original rich, embedded meanings. While the initial damage cannot be undone those of us who teach Sanskrit have to also share the blame for perpetuating the same vocabulary in our teaching even today. Just as we have retained German words to express ideas such as Weltanschauung, Lebenswelt etc., we should try and use words like 'atman', 'darsana', 'deva', 'dharma', 'duhkha', 'jnana', 'samsara', etc., to denote their specific meanings in the classrooms after initially introducing them.

In the concluding chapter called "Purva Paksha and the Way Forward" (338f) Rajiv has thrown the gauntlet and challenged intellectuals belonging to both traditions to "perceive" the policy of 'secularism' that was developed in the west and which is now spreading across the globe as fundamentally flawed. Defining 'sapeksha-dharma' as "engagement with reciprocity and mutual respect" (p. 340) he argues for its replacing 'secularism' as befitting India's multi-religious and multi-cultural society as also an alternative to western secularism (p.341). He calls for an honest debate in the "purvapaksha-style" of the Indian philosophical commentary literature that can eventually reach a mutually amicable settlement. However, one needs to remember that the Sanskrit philosophical commentarial literature, while willing to consider prima facie views as a foil to the metaphysical and epistemological theories propounded in the sastra text they were dealing with, still had the overall aim of reinforcing the tradition's own 'siddhanta' regarding these matters. So the Sanskrit "purvapaksha" methodology advocated by Rajiv is to follow the methodology without any preconceived conclusions. A tall order indeed, as I can cite from my own example given below.

There was a suggestion by an inter-faith group in Canada to invite religious scholars from different faiths to study another religious faith other than their own and then engage in a discussion as to the way they viewed this other tradition. While I, a Hindu, readily agreed to study any other religion which would be assigned to me there were no other takers for this from the other religious traditions. What could have been a pioneering effort in the right direction somehow died a premature death. Thus Rajiv's proposal which is somewhat similar, is 
bound to raise a number of critical issues, and I wish it would succeed "since the ethic of mutual respect would trump the differences" (p.341).

While what Rajiv states regarding "Dharma scholars" reluctant to turn their gaze and study of the Judeo-Christian tradition (p.345) is largely true today, there have been reformers like Ram Mohun Roy and Dayananda Saraswati who did "turn their gaze" to study western and Islamic religious traditions. Ram Mohun Roy in particular also engaged in debates with Christians and translated the four Gospels into Bengali. He even helped in the establishment of the Calcutta Unitarian Committee. Rajiv's warning that there are no traditional dharma scholars comparable to the westerners trained in "Western seminaries where comparative world religions are seriously taught in order to prepare future leaders with the knowledge necessary to engage with other religions" (p.345) is indeed very true. This lacuna has to be attended to, giving it the highest priority if there has to be any serious dialogue between the two traditions.

This is a book that can be read by those interested in promoting an honest dialogue between different religious traditions. But there are some factual errors which need to be corrected. For instance, note 109 given in the notes on pages 431-32 does not have a corresponding mark within chapter 5 itself. The statement on page 196 that Sri Krishna killed Bhisma is wrong. It was Arjuna's arrows that pierced Bhisma. Krishna only advised Arjuna to place Sikhandin in front so that Bhisma could not retaliate by shooting back with arrows, as it would first kill Sikhandin before reaching Arjuna. Why Bhisma would not kill Sikhandin is too complicated to be narrated here. Page 399 n.51 has Sayanacarya spelt incorrectly as Sayabacharya. However these lapses are very few and far between and cannot substract from the overall wealth and richness of information that is packed into this book. In a larger sense both Hindus and followers of other religions can benefit from reading this book, if done with an open mind. A lot of not so well known facts regarding the different religious traditions are covered. One hopes that in this age of globalization when the world is becoming one 'flat land' mutual respect for the cultures of different peoples will come sooner rather than later. Books of this kind might help in that direction.

T. S. Rukmani

Concordia University

\section{Many Ways of Pluralism: Essays in Honour of Kalarikkal Poulose Aleaz, Edited by V. J. John, 2010, Delhi: ISPCK \& Bishop's College, pp. $\mathrm{x}+347$. ISBN: 978-81-8465-045-7.}

MANY Ways of Pluralism is a festschrift published in honor of Rev. Dr. K. P. Aleaz who has been serving for the past thirty-two years at Bishop's College, Kolkata. This volume consists of eighteen essays contributed by his contemporaries, associates and students as a tribute to a committed professor and renowned scholar for his enormous contribution to theological education, particularly through his extensive writings in the areas of Indian Christian theology and theology of religions.

The content of the book is categorized into two parts. In the first section the various writers explore pluralistic inclusivism from the perspectives of the different disciplines such as:
Christology, Subaltern and Dalit perspectives, Christian Education, Missiology and Spirituality. The various essays in the second section emphasize considering the differing contexts of India as essential in the task of theologizing, such as disability, marginalization, pluriform religiosity and primal traditions. Scholars from diverse backgrounds and traditions have explored whether pluralistic inclusivism can offer relational pro-existence in a multi-cultural and multi-religious context to overcome violence.

The book begins with D. Isaac Devadoss's essay on "Life and Evolution of K.P Aleaz's Thought." The first section deals with his early 